Bangladesh J. Plant Taxon. 27(2): 345-358, 2020 (December)

(C) 2020 Bangladesh Association of Plant Taxonomists

\title{
BIBLIOGRAPHICAL NOTE ON THE SYNTAXONOMY OF THE VEGETATION OF TLEMCEN, HAFIR, MOUTAS AND ITS RESERVE (NORTH-WESTERN ALGERIA)
}

\author{
Naima Bouazza*, Kouider Cherifi, Brahim Babali ${ }^{1}$ \\ AND MOHAMmed Bouazza ${ }^{2}$
}

Laboratory of Plant Biodiversity, Conservation and Valorisation, Djillali Liabès

University, BP 89, Haï Larbi Ben M'Hidi, Sidi Bel Abbés 22000, Algeria

Keywords: Hafir; Moutas reserve; Phytoecology; Regressive evolution; Syntaxonomy; Tlemcen.

\begin{abstract}
This study provides bibliographical note on the syntaxonomy of the vegetation of Tlemcen, Hafir, Moutas of North-western Algeria, including the associations and alliances of the different higher units found in the Hafir forest and the Moutas Reserve. In this work, we observed modifications of forest and pre-forest structures according to bioclimatic variations. However, in this region, the xericity of the climate is not the only factor destroying the plant cover, anthropization is also a degradation factor. While being aware of the negative consequences, man, through their abusive cultivation, illegal logging, overgrazing, urbanization, the depletion of natural resources; inhibits the evolution of vegetation, participates in the replacement of a rich plant cover by another and more xerophytic plant cover with thorny and/or toxic feature. The landscape is dominated, for the most part, by open and degraded formations based on therophytes and chamaephytes, linked to Rosmarinetea and Cisto-Lavanduletea. The tree structures in Hafir and the Moutas reserve, still occupy only minimal areas subject to the destructive actions of man and his flock. These formations are still linked to the Quercetea ilicis. These ecosystems are marked by a regressive evolution (forest, pre-forest, scrub, scrubland and therophytization).
\end{abstract}

\section{Introduction}

In the Mediterranean basin, the forest area requires some ecological and socio-economic importance. In addition, Algerian forests, like Mediterranean forests, present significant natural resources, including a proven floristic diversity (Quézel and Médail, 2003). The forest and preforest ecosystem study has the particularity of never ending (Quézel, 2000).

The status of forest, pre-forest and pre-steppe schrulands structures were clarified in Morocco by Quézel and Barbero (1981), Benabid (1985) in Tunisia by El hamrouni (1992) and Chaabane (1993), in Algeria by Djebaili (1984, 1990), Dahmani (1984), on the mountains of Tlemcen and Bouazza (1991, 1995), Amara and Bouazza (2013) on the Tlemcen region and Babali (2014) on Hafir and the Moutas reserve.

The Tlemcen Mountains forests offer a very interesting model for studying the flora and vegetation evolution. The variety of landscapes, but also their differences, remain very remarkable, their distribution is conditioned by a large number of ecological factors. They are characterized by mixed groups of holm oak and Zeen oak in Hafir and Zarifet forests. Elsewhere, these are degraded groupings (Dahmani, 1997).

*Corresponding author, email: naiman37@yahoo.fr

${ }^{1}$ Laboratory of Ecology and Management of Natural Ecosystems, Aboubekr Belkaid University, Tlemcen, Algeria.

${ }^{2}$ BP 18. K Tlemcen, Algeria. Email: Lecgen_tlm@yahoo.fr. 
It is important to underline that the data relating to vegetation tend to bring the territories closer together, to highlight their affinities and subsequently to better understand their real phytosociological originality. Of course, this is linked to the fact that vegetation is the result of the integration of floristic, climatic, geological, historical, geographic, edaphic and anthropic factors.

We have tried through this note to synthesize interesting data available from the Tlemcen region: Hafir and the Moutas reserve.

\section{Materials and methods}

Geographical location of the study site

The Tlemcen region is located in the western part of northwest Algeria (Fig. 1). The study area is located between $34^{\circ} 25^{\prime}$ and $35^{\circ} 25^{\prime}$ North and $0^{\circ} 55^{\prime}$ and $2^{\circ} 30^{\prime}$ West, with an area of approximately $9000 \mathrm{~km}^{2}$.

It is geographically limited: In the north by the Mediterranean sea, in the north-east by the wilaya of Aïn Témouchent, in the east by the wilaya of Sidi Bel-Abbès, to the west by the Algerian-Moroccan border, and in the south by the wilaya of Naâma.

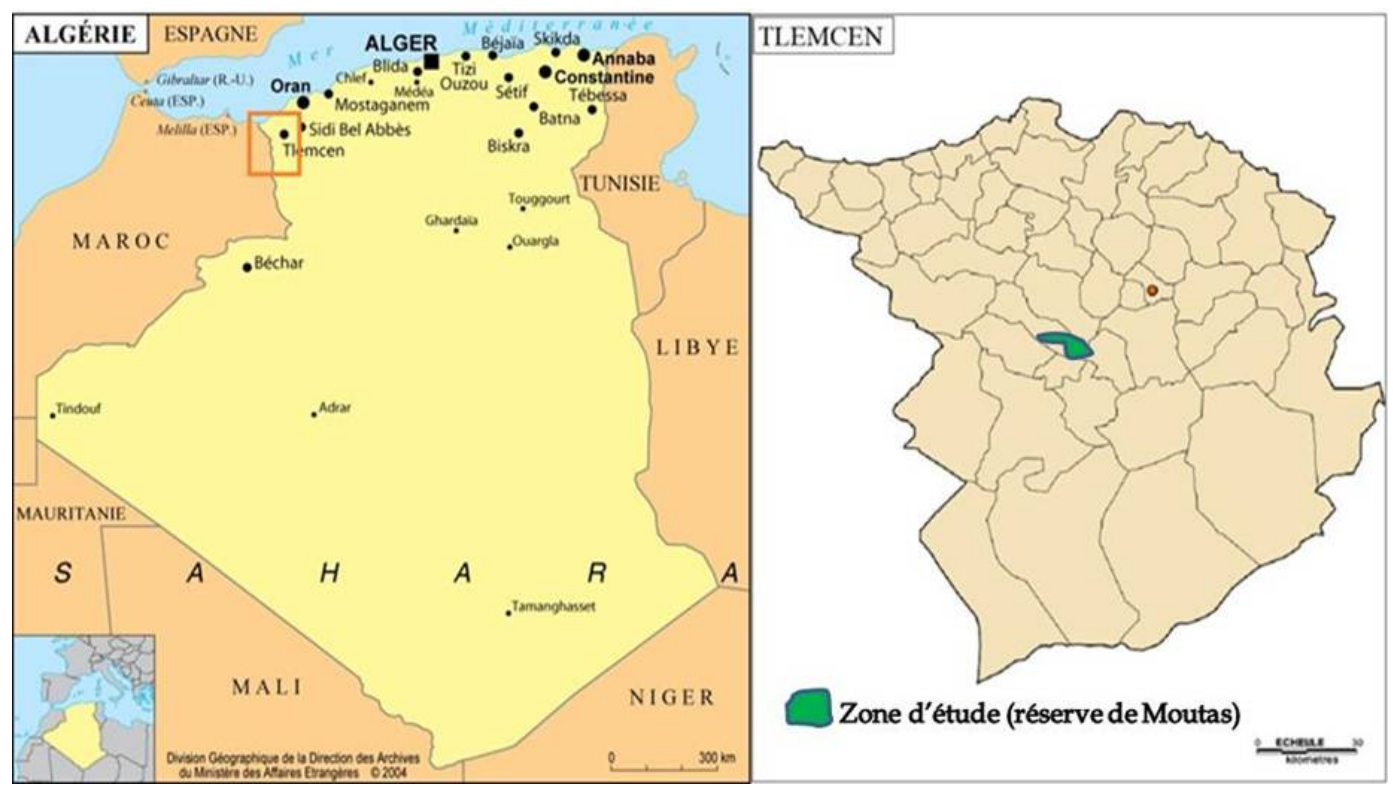

Fig. 1. Geographical map of the study area.

The climate

The Tlemcen region is characterized by a Mediterranean type climate: (i) Short, cold mild winters run from October to March, characterized by irregular rainfall. (ii) Long hot and dry summers: marked by average rainfall and hot weather which ranges from 6 to 8 months.

In this region, two bioclimatic stages exist and dominate: the semi-arid and the sub-humid. The monthly and seasonal variations in main climatic characteristics ( $\mathrm{P}$ and $\mathrm{T}$ ) depending on the altitude and the distance from the sea, have been highlighted in Fig. 2. These variations show a comparison between the old meteorological data (1913, 1938 - Seltzer, 1946) and the new data (1975- 2016). 
There is a clear decrease in rainfall and an increase in temperatures (in most stations). These results agree with the hypothesis of climate change in the study stations which evolve towards a more marked aridity (Bouazza and Benabadji, 2002, 2010; Babali et al., 2018). These climatic conditions directly influence the vegetation dynamics in a regressive direction (Bouazza and Benabadji, 2000).
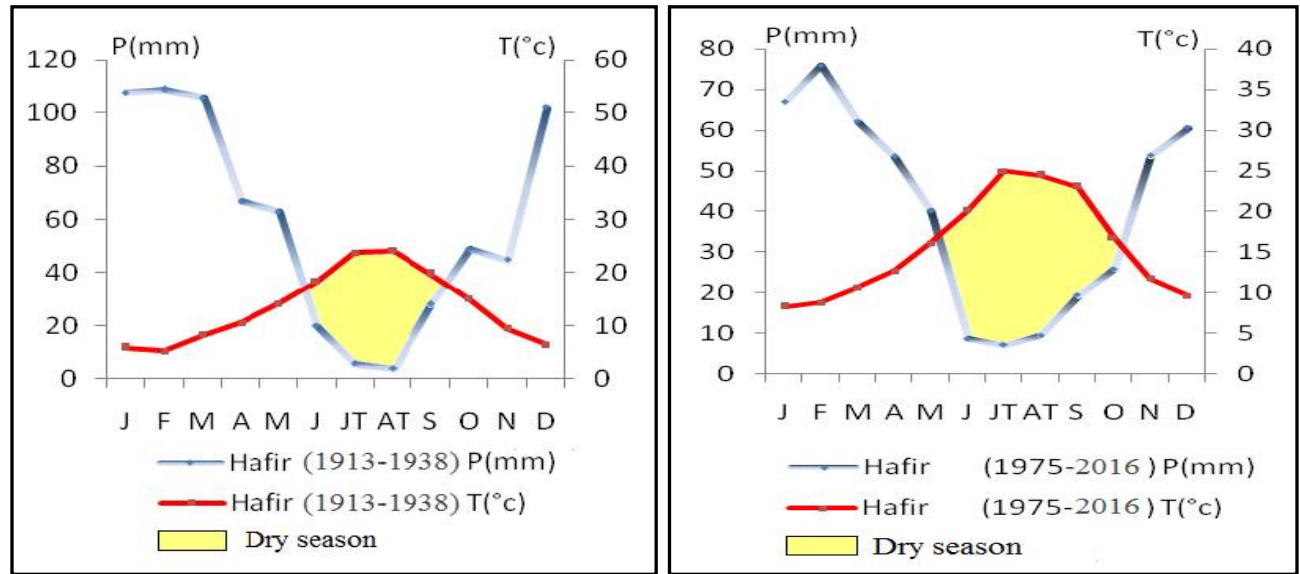

Fig. 2. Bagnouls and Gaussen ombrothermal diagrams. Old period (1913-1938: Seltzer, 1946); recent period (1975-2016) P: Rainfall $(\mathrm{mm})$ and T: Temperatures $\left({ }^{\circ} \mathrm{C}\right)$.

\section{Methodology}

One hundred surveys were carried out according to the conceptions of phytoecology and the floristic inventory based on the tree, shrub and herbaceous strata. The surveys were made on floristically homogeneous surfaces (Guinochet, 1973, 1977). This important notion for the quality of information has been associated with that of minimum area (Gounot, 1969). The latter plays a role of first order, because it allows the floristic comparison of spatially dispersed surveys. It varies according to each plant group. In this regard, Djebaili (1984) pointed out that the flora richness depends essentially on the number of annual species present at the time of the survey. This, and consequently the minimum area, will also depend on the vagaries of annual and interannual rainfall. According to Gounot (1969), the commonly used method consists in listing the species on a plot with a very small surface area. Then double this surface $(1+2)$ and add the new species that appear. By successive doublings, we are supposed to arrive at a surface $(1+2+\ldots$ $+n$ ) from which there are no longer (or practically no more) new species appearing. In reality, however, as we add new surfaces to the previous surface, there are always new species that appear more or less sporadically. In our case study, the floristic surveys, on a surface of $100 \mathrm{~m}^{2}$ were carried out on the whole of the distribution area of the plant formations lay the favorable periods of the vegetation.

As Goodall (1952) noted, the method is not statistically correct, because if a species rare in the plant community was encountered in the initial plot, it will appear in all subsequent plots. Indeed, it would be more exact to operate on the series of plots of increasing size, taken at random in the community, without the small plots being systematically included in the large ones. This brings us to an average number of species included in the large ones. Each of our statements includes: the location of the statement, the list of species, the recovery rate, the altitude, the exposure, the slope, the substrate. 
We have made a synthesis of two working methods that of the minimal area and the method of transect, this fusion allowed us to have relevant results at the level of the whole station.

Outside of the study stations, we have adopted the floristic network; which consists in multiplying the surveys in order to get the maximum of information; this helps us to identify rare and endemic species and to complete the floristic list. This choice is motivated by the work speed (to save time) and by the flora richness.

\section{Results and Discussion}

After consulting the various floristic surveys carried out on the entire study site, the plant formations identified are as follows:

Class of Quercetea ilicis (Braun-Blanquet, 19) (1947)

In this unit are gathered circum Mediterranean sclerophyllous formations. We used the work of Rivas-Martinez (1974), Barbero et al. (1981), Medail et Quézel (1996) Quézel and Medail (2003) and in particular for Algeria and the Tlemcen region: Dahmani (1984, 1996, 1997), StambouliMeziane (2010), Amara and Bouazza (2013), Babali (2014), Belhacini (2015) and Bouazza et al. (2015).

The characteristic species mentioned by the authors are: Arbutus unedo, Asparagus acutifolius, Arisarum vulgare, Bupleurum rigidum, Rosa sempervirens, Rubia peregrena, Smilax aspera and Pulicaria odora. Of the species encountered in Hafir and the Moutas reserve, we cite: Asparagus acutifolius, Arisarum vulgare, Juniperus oxycedrus, Rubia peregrina, Olea europea, Phillyrea latifolia, and Rosa sempervirens.

Orders of Quercetalia ilicis (Braun-Blanquet 1947)

This order includes the forest formations dominated by sclerophyllous oaks (Quercus ilex, Quercus suber and Quercus coccifera) and (Quercus faginea subsp. tlemceniensis) linked to the humid and sub-humid thermo, meso and supra-Mediterranean stages.

The species of this order are: Carex distachya, Cytisus arborens, Cytisus villosus, Moerhingia trinervia subsp. pentandra, Phillyrea latifolia, Quercus faginea subsp. tlemceniensis, Quercus ilex, Quercus suber, Ruscus aculeatus, Teucrium pseudo-scordonia and Viburnum tinus.

In this region (Hafir and the Moutas reserve), there are groups linked to two recognized alliances in Morocco and Tunisia: (i) Oleo sylvestis-rotundifolio suberis Barbero (Quézel and Rivas-Martinez, 1980; Bouazza and Benabadji, 2002, 2010). (ii) Balansaea globerinaea, Quercium rotundifolia Babero (Quézel and Rivas-Martinez 1980).

In addition, on siliceous substrates we find a western Mediterranean alliance: Quercion suberis (Loisel, 1971) which appears in North Africa. To this alliance we must integrate, for Hafir and the Moutas reserve, Cytiso triflori-Quercetum suberis, Centauretosum taganae, described by Dahmani in 1984.

We find the following 3 alliances that relate to the Quercetalia ilicis in Morocco and Tunisia: (i) Oleo sylvestris-Quercion rotundifolio suberis Barbero (Quézel and Rivas-Martinez, 1980). (ii) Balansaeo globerrinae-Quercion rotundifolio Barbero (Quézel and Rivas-Martinez, 1980). (iii) Medicago tunetanae-Crataegion azaroli (El Hamrouni, 1992)

In Algeria, this order is represented by 3 other alliances: (i) Querco rotundifoliae-Oleion sylvestris Barbero (Quézel and Rivas-Martinez, 1980). (ii) Balansaeo globerrinae-Quercion rotundifolio Barbero (Quézel and Rivas-Martinez, 1980). Quercion suberis (Loisel, 1971). 
Order of Pistatio-Rhamnetalia alaterni (Rivas-Martinez, 1974)

This order brings together pre-forest structures resulting from intense degradation of forest formations in humid and subhumid bioclimates. In the semi-arid and arid, this is the only potential climax (Barbero et al., 1981; Dahmani 1997). It is characterized by: Ampelodesma mauritanicum, Asparagus stipularis, Daphne gnidium, Chamaerops humilis subsp. argentea, Clematis cirrhosa, Clematis flammula, Jasminium fruticens, Osyris alba, Pistacia lentiscus, Pistacia terebenthus, Quercus coccifera, Myrtus communis and Ephedra fragilis.

Hadjaj-Aoul (1995), Bouazza and Benabdji (2002, 2010), Hasnaoui (2008) and Mesli et al. (2009) point out that in Oranie, the pre-forest formations are rather integrated into the PistacioRhamnetalia alaterniorder.

The following alliances have been recognized in Algeria; most are represented in the Tlemcen region (Hafir and the Moutas reserve). (i) Asparago-Rhamnio oleoïdes (Rivas-Goday,1964; RivasMartinez, 1974), which groups together certain tetraclinaies (callitris) from western Algeria (Dahmani, 1984 and Hadjadj-Aoul, 1988, 1991). (ii) Calycotomo intermediae - Quercion cocciferae (Dahmani, 1997), which in Oranie brings together pre-forest associations dominated physiognomically by the Calycotome intermedia associated to Chamaerops humilis. This alliance will replace in Western Algeria the Genisto tricuspidatae calycotmion spinosi (Dahmani, 1997) from central Algeria. (i) Ericion arboreae linked to siliceous substrates with Arbutus unedo, Erica arborea and Buplerum fruticosum.

To these alliances, present in the area, we should associate the Junipero oxycedri-Rhamnion developed in the Saharan Atlas and the southern slope of the Tlemcen mountains; and the alliance with Calycotome spinosa and Thymus munbyanus subsp. coloratus proposed by Gharzouli (1989) in eastern Algeria (association bearing Chamaerops humilis).

In Oranie, this alliance is replaced by its vicariant: Calycotomo intermediae- Quercion coccifera (Quézel et al., 1992) which brings together the association of Calycotomo intermediae Quercetum rotundifoliae. The Therophytes strong presence, because of the environment anthropization, results in the birth of an association defined by Quézel et al. (1992) and Quézel and Medail (2003): Ampelodesmo-mauritanicum-Chamaeropetum humilis which extends over the Tessala and Traras Mountains, and in some cases in the Tlemcen Mountains on the north-east slopes. We also meet it in eastern Morocco.

Within the Pistacio-Rhamnetalia alaterni; Hadjadj-Aoul (1995) described a new association: Ampelodesmo mauritanicum-Tetraclinetum articulatae which in turn contains a sub-association which reflects the pre-forest aspect derived from a green oak tree called Chamaeropetosum humilis at altitudes ranging from 700 to $1300 \mathrm{~m}$.

The groups subservient to Calycotomo-Quercion would settle following the deterioration of the tetraclinaie, the cocciferaie or even the green oak of the upper thermo-Mediterranean and the lower meso-Mediterranean. If Calycotome intermedia and Ampelodesma mauritanicum characterize the order of Pistacio-Rhamnetalia alaterni in semi-arid bioclimate; they play a preponderant role in open environments, like the Calycotome in the class of Cisto-Lavanduletea in southern Europe.

However, as the Calycotome is a species very characteristic of relatively open shrubland and heavily degraded scrubland (Cherifi et al., 2011, 2017), we would like to link it, as well as Chamaerops humilis subsp. argentea to the Rosmarinetea class. Also, it is absolutely excluded to be able to recognize these two species as characteristics of the Pistacio-Rhamnetalia alaterni. It is true, that with these two species, the sylvatic atmosphere reigns there in certain cases, but not to the point of excluding them from Rosmarinetea. 
Class of Rosmarinetea-Officinalis: (Braun-Blanquet 1947; Rivas Martinez et al., 1991)

The intense degradation of the pre-forest groupings favors the installation of shrublands integrating into the classes of Rosmarinetea or Cisto-Lavanduletea according to the limestone or siliceous nature of the substrate. This class includes shrub associations and certain swards based on chamaephytes and therophytes. It is frequent all around the western basin of the Mediterranean. In Algeria, Djebaili (1990) links two orders to this class: (i) Rosmarinetalia (Braun-Blanquet, 1931 and 1952) with a largely oro-mediterranean distribution. (ii) Thymoïsti-Juniperatalia phoeniceae (El Hamrouni, 1978), which is believed to be from the Maghreb.

Two orders have been described in Morocco and taken up by Dahmani (1997): (i) Cisto mauritanici-thymetalia munbyani, (ii) Anarrhino fruticosi astragaletalia armati.

Among the alliances retained in the Cisto-mauritanici-Thymetalia munbyani, Quézel et al (1992) also bring together the tellian shrublands: (i) Ulici africani-Rosmarinion toumefortii defined by Quézel, Barbero, Benabid, Loisel and Rivas-Martinez in 1992, to characterize the north-western shrublands of Algeria. These groups derive from the degradation of the tetraclinaie (Hadjadj-Aoul 1995; Bouazza and Benabadji 2002, 2010; Hasnaoui 2008; Bouazza and Benabadji, 1998). (ii) Staehelino macrocephalae-Genistion pseudoretamoïdes, (Quézel et al., 1992; Dahmani 1997). This alliance is also present in the continental area with semi-arid climate. It is marked by the presence of Genista erioclada, Genista spartioïdes subsp. pseudoretamoïdes, Staehelina dubia subsp. maeroeephala and Thymus mynbyanus var. intermedia. (iii) The Genisto atlanticae-Cistion villosialliance, described by Dahmani (1984), brings together in the region of Tlemcen (Hafir and the reserve of Moutas), the shrublands of the semi-arid continental zone in the MesoMediterranean. It brings together the following species: Centaurea lagascae subsp.spachii, Cistus creticus, Cistus villosus, Festuea scaberrima subsp. africana, Fumana fontanesii, Genista erioclada subsp. atlanticae and Genista spartioids subsp. pseudoretamoïdes. In this alliance, three units characterizing the stages of pre-forest formationsdegradation are integrated: (iv) Helianthemo racemosi-Genistetum atlanticae-globularietosum which contains the rosorrinus, Globularia and Stipa shrublands with some species belonging to Quercetea ilicis. (v) Helianthemo racemosi-Genistetum atlanticae-pinetosum, marked by a rarity of characteristic species. (vi) Centaureo ternifoliae - Genistetum atlanticae - stipetosum tenacissimae, which shows the regression towards the steppe groupings at Alfa.

The order of Anarrhino fruticosi - Astragaletalia armati (Quézel et al., 1994), taken up by Dahmani (1997) is more steppe, represented by Mediterranean-Saharan transition species. This order is present in Morocco, it is represented by a set of species which characterizes it: Anarrhinum fruticosum, Astragalus armatus subsp. armatus, Atractylis humilis subsp. coespitosa, Bupleurum atlanticum subsp. Atlanticum, Convolvulus valentinus subsp. coespitosus, Coronilla juncea subsp. pomelii, Echium humile, Fumana ericoüdes var. scoparia, Genista uniflora, Herniaria fontanesii, Hippocrepis montana Linum austriacum subsp. gaetulum, Polycnemum fontanesii, Ormenis africana, Thymelaea virescens and Thymus munbyanus subsp. coloratus.

As in Morocco, Tunisia and Algeria, the Helianthemo ruficomi-Genistion tunetanae alliance is gaining momentum, it is closer to that of Pinus halepensis and Juniperus turbinata already described by Le Houerou (1969).

The differentiation that exists between the groups of the Anarrhino fruticosi- Astragaletalia armati and those of the Lygeo-stipetalia lies in their position in a steppe environment (Quézel et al, 1992; Bouazza and Benabadji, 2002, 2010).

The associations selected by Dahmani in 1984 and which are developing in the Tlemcen region (Hafir and the Moutas reserve) held our attention. 
These associations include the following sets of vegetation: Helianthemo racemosiGenistetum atlanticae: this grouping derives from the degradation of pine forests, green oak groves, with or without Kermes and Cedar oak (Quercus coccifera and Tetraclinis articulata): Beni Saf and the southern slope of the Tell and Western Atlas and Tlemcen region (Hafir and the Moutas reserve). These open formations allow the extension of Rosmarinus, Globularia, Stipa and Ampelodesma (Hasnaoui, 2008; Stambouli-Meziane, 2010 and Belhacini, 2015).

Two sub-associations mark the thermophilic aspect: Globularietosum alypi which is characterized by Ononido-Rosmarinetea species such as: (i) Globularia alypum, Fumana thymifolia, Helianthemum pilosum and Cisto sericens (ii) Pinetosum recognizable by Pinus halepensis and its richness in species of Therobrachypodietea swards, in connection with the strong degradation of the environment (Bouazza and Benabadji, 2010 and Chiali, 1999). (iii) The Helianthemo pilosi-Thymetum munbyani group contains in particular the Stipa, Ampelodesma, Asphodelus, Genista atlantica, Thymus munbyanuslow shrublands; we meet it between the Quercus ilex, Ampelodesmaformations, with or without the presence of Stipa, and the Ampelodesmaies or the chamaeropaies. This association stems from the degradation of Centaureo temifoliae-Genistetum atlanticae, endemicto Oranie (Dahmani, 1984).

The various associations analysis allowed us to take stock of the high degree of degradation, either anthropogenic or ecological (erosion, fire, grazing, etc.), reflected by the penetration of numerous therophytes with a nitratophilic tendency.

This class is not easy to read because of its interpenetration with other classes. It is characterized by its open and degraded appearance, something which led us to link all Chamaerops humilis subsp. argentea, Calycotome intermedia and several chamaephytes.

Cisto-Lavanduletea class

The characteristic species are: Cistus salvifolius, Cistus villosus, Lavandula stoechas, Lavandula dentata, Halimium umbellatum, Halimium halimifolium and Tuberaria major.

This class, well represented in Algeria (Kabylia), is poorly known in the Tlemcen region (Hafir and the Moutas reserve). This class is characterized by its open and degraded feature, something which led us to link to this class all the species which result from a degradation like Chamaerops humilis subsp. argentea and Calycotome intermedia, as well as several Chamaephytes and therophytes.

Our region is exposed to a significant degree of degradation, to such an extent that the palatable species disappear quickly and are replaced by others, toxic and thorny.

\section{Tuberarietea guttatae class}

This class brings together ephemeral xerophytic swards of Mediterranean origin characterized by the species that are frequently encountered in our study area; but few in number compared to Therobrachypodietea and, in the same ecological context, it is characterized by the rarity of palatable and non-dominant species: Scorpiurus muricatus, Atractylis concellata, Sideritis montana, Lagurus ovatus, Medicago minima, Evax pygmea, Arenaria scipillifolia, Hyppocrepis ciliata, Leontodon rothii and Trifolium stellatum.

This class brings together three orders with only the first two which are represented in Algeria: (i) Brachypodietae distachya (Rivas-Martinez 1977) (ii) Tuberarietalia guttatae BraunBlanquet (1940) (iii) Malcornietalia (Rivas-Goday 1957).

The latter is characteristic of the Iberian Peninsula. However the order of Lygeo-stipetalia Braun-Blanquet and De Bolos (1957) which was always linked to the Therobrachypodietea was separated by Rivas-Martinez (1977) to attach it to the Lygeo-stipeteaclass.It seems to us preferable 
to keep the previous status, because it is well represented at the southern slopes in our area by perennial Poaceae (Bouazza et al., 2001 and Babali et al., 2013).

On Silica:

Tuberariaetalia guttatae settles on the southern slope in the study area. The characteristic species are: Aira cupaniana, Aira tenorei, Briza maxima, Catapodium tenellum, Logfia gallica, Limun fugerium, Lotus conimbricencis, Ornithopus compressus, Rumex bucephalophorus, Tolpis barbata, Trifolium arvensis, Trifolium glomeratum, Trifolium subterraneum, Tuberaria guttata, Vulterata gumberata and Vuipia myuros.

On limestone:

Brachypodietalia distachyae (Rivas-Martinez, 1977) settles down and groups therophytic species; they are numerous and we have kept in our area the following species: Bromus rubens, Brachypodium distiachyum, Aegylops triuncilis, Linum corumbiferum, Xeranthenum inapertum, Plantago albicans, Medicago rugosa, Ammoides verticillatae Convö̈vulus, Bellis annua, Trifolium angustifolium, Allium triquetum, Pallenis spinosa, Echium vulgare, Malva aegyptiaca, knautia arvensis, Convolvulus tricolor, Atractylis concellata, Buplerum semi-compositum, Echinaria capitata, Euphorbia exigua, Galium parisusus, Micropus suminus and Trachynia distachya.

It is important to note two other alliances: (i) Thero-Brachypodion Northwest of the Mediterranean (Braun-Blanquet, 1925) (ii) Stipion capensis North Africa and Spain (BraunBlanquet, 1954)

Nevertheless, it seems likely to us that the calcifuge therophytes, of Hafir and MoutasReserve, constitute units to be attached to the order of Tuberarietalia guttatae.

Class of Lygio-Stipetea

The Lygio-Stipetea class (Rivas-Martinez and Izco, 1977) brings together perennial herbaceous associations, very widespread in Spain. Three alliances characterize the Mediterranean steppes and are attached to this order: (i) Eremopyno-Lygeion: Iberian, (ii) Stipion retortae: IberoMauritanian, (iii) Stipion tenacissimae: North African.

This class includes the following species: Atractylis cancellata, Atractylis serratuloïdes, Calendula aegyptiaca, Echium humile, Eryngium ilicifolium, Helianthemum apertum, Plantago ovata, Reichardia tingitana, Stipa parviflora, Plantago serraria and Plantago albicans.

The three species of the Tlemcen region are marked by different frequencies and are present on both sides. Stipa parviflora is observed near Rosmarinus and Erica in the Beni-Saf region, to characterize a pre-forest formation.

In Algeria, and more particularly in the Oran Tell, Guinochet (1973) proposed the Atractylostipion alliance which was also reported in Tunisia by Chaabane (1993). The class of Tuberarietea guttatae was also adopted by Aime (1991) who, in his work, integrates it among the dry therophytic swards of the thermo-Mediterranean. The abundance of these swards in our study area testifies to the intense anthropozoogenic influence (Bouazza, 1991 and Babali, 2014).

Two other classes, described by Dahmani (1997) in our area, and which are also linked to anthropozoogenic pressure, are: Thero-Brachypodietea guttatae and Stellarietea mediae.

The Thero-Brachypodietea class characteristics are numerous and the characteristic species are: Bromus rubens, Brachypodium distachyum, Aegilops triuncialis, Linum corymbiferum, Xeranthemum inapertum, Plantago albicans, Medicago rugosa, Ammoid verticillata, Convolvulus althaeoid, Bellisolifoli triquetrum, Pallenis spinosa, Echium vulgare, Malva aegyptiaca, Knautia arvensis and Convolvulus tricolor. The ecological range of these taxa is wide; they are 
encountered from the south of Sebdou to the Oran coastline, including the Hafir and the Moutas Reserve area, and undoubtedly constitute one of the groupings of the Meso and ThermoMediterranean stages.

The Tuberarietea guttatae class brings together ephemeral xerophytic swards of Mediterranean origin characterized by the species that are frequently encountered in Hafir and in the Moutas reserve, but few in number compared to Thero-Brachypcdietea in the same ecological context with a rarity of palatable and non-dominant species: Scorpiurus muricatus, Atractylis cancellata, Sideritis montana, Lagarus ovatus, Medicago minima and Evax pygmea. This class brings together three orders with only the first two which are represented in Algeria (Dahmani, 1997):

(i) Brachypodietalia distachyae (Rivas-Martinez and Izco, 1977), (ii) Tuberarietalia guttatae (Rivas-Goday, 1957), (iii) Malcolmietalia (Rivas-Goday, 1957).

Brachypodietalia distachyae (Rivas-Martinez, 1977) brings together basiphil therophytes, which become dry in summer, characterized in our area by: Atractylis cancellata, Xeranthemum inapertum, Plantago afra, Herniaria hirsuta and Trifollium stellatum.

In this order, there are 4 alliances: (i) Therobrachypodion (Braun-Blanquet, 1925), (ii) Stipion capensis (Braun-Blanquet, 1954), (iii) Seda-Ctenopsion gypsophilae (Braun-Blanquet, 1965), (iv) Omphalodion brassicifoliae (Rivas-Martinez, 1987).

Only one alliance derives from this set, that of the Thero-Brachypodion, with the following characteristics (present in Hafir and the reserve of Moutas): Micropus bombycinus, Paronychia argenatea, Galium mollugo, Salvia verbenaca, Scabiosa stellatum and Hippocrepis multisiliquosa. We have encountered these different species on various types of substrates. We take the example of Paronychia argentea found, and healthy, on limestone soil as on siliceous soil, accompanied by Scabiosa stellata and Trifolium stellatum.

Tuberarietalia guttatae (Rivas-Goday, 1957): the characteristic species are therophytic communities which prefer siliceous grounds, and develop on shallow and not very acid soils, with sandy or silty texture.

This order is very weakly represented in the groups of our study area. It contains the following species: Aira cupaniana. Aira tenorei, Briza maxima, Catapodium tenellum, Logfia gallica, Linum fugyrium, Lotus coninbricensis, Ornithopus compressus, Tolpis barbata, Trifolium arvense, Trifolium glomeratum, Trifolium ligustieum, Trifolium subterraneum, Tuberaria guttatae and Vulpia geniculata.

Apart from the Briza maxima species, which frequently occur in our surveys (north slope) and which is reported among the Tuberarion guttatae (Braun-Blanquet, 1931), the other species characterizing this order are absent. This alliance has two associations:

Filago pyramidatae-Plantaginetum Iagopi (nov. Ass.) observed in open holm oak from the Tellian Atlas to the semi-arid and subhumid meso-Mediterranean (Traras mountains, Tlemcen region, Mascara, Tiaret, Ouarsenis, Bougaa and Babors). This association is either in the form of Ampelodesma mauritanicum fruit trees, hence the sub-association Ampelodesmetosum mauritanicum, or in the form of Calycotome and Quercus ilex suckers, or in the form of herbaceous swards.

Among the characteristics of this one we have: Bachypodium distachyon, Hedypnois rhagadioloïdes, Filago pyramidata, Pallenisspinosa, Plantago lagopus, Plantago serraria and Eryngium tricuspidatum. The latter is also retained as a characteristic of Ononido-Rosmarinetea: Pallenis spinosa, Plantago lagopus, Plantago serraria also derive from Stellarietea mediae which, by their floristic clump, characterize the most accessible areas to herds. 
Echinario capitatae-Euphorbietum falcatae (nov. Ass.): This association follows the StipaQuercus ilex-Ampelodesma-Juniperus oxycedrus (Centaurea tenuifoliae-Genistetum atlanticae) formations. The dominant species are more attached to the Thero-Brachypodion.

\section{Class of Stellarietea Mediae}

Also called Rudero-Secalietae Braun-Blanquet (1936); it groups nitratophilic annuals and has been the subject of numerous writings: (i) in Tunisia: Guinochet (1977) and Chaabane (1993), (ii) in Spain: Rivas-Martinez and Izco (1977), (iii) in Algeria: Dahmani (1996), Abdelkrim (1995) and Bouazza (1991, 1995).

In our area (Hafir and the Moutas reserve), this class is characterized by the following species: Avena sterilis, Calendula arvensis, Hordeum murinum, Bromus rubens, Aegilopstriuncialis, Ornithogalum umbellatum. Convolvulus althaeoïdes, Sinapis arvensis, Anagallis arvensis, Biscutella didyma, Trifolium angustifolium, Centaurea pullata, Paronychia argentea, Allium roseum, Bellis апnиа and Erodium moschatumIt is likely that this unit will undoubtedly dominate the landscape of Hafir and the Moutas Reserve in the near future. Two orders are retained by Dahmani (1997) in his work on Algerian green oak groves:

- Secalinetalia: brings together the swards associated with crops on limestone soil and characterized by the following species: Asperula arvensis, Androsace didymas, Bunium pachypodium, Centaurea pullata, Coronilla scorpiö̈des, Lithospernum arvensis, Ornithogallum umbellatum, Papaver hybrideus, Sinapis arvensis and Silene vulgar.

- Brometalia rubenti-tectori: brings together the sub-nitraophilic annuals with the following characteristics: Aegilops triuncialis, Bromus rubens, Reichardia picriö̈des, Allysum granatense, Bromus teetorum, Daucus muricatus, Galactites elegans, Plantago lagopus, Hypochoeris aehryphorus, Hinachfeldia, Hinachfeldia and Hedypnois rhagadioloïdes.

The floristic complexity of the vegetation in the Tlemcen region appears to be the result of the anthropo-climatic effects which have occurred there over the past thirty years. The use, or even the overexploitation, by man and his herd, of this vegetation, largely contributed to the vegetal cover degradation.

However, it is in the most accessible areas (non-accidental relief, tracks, roads) that this process is particularly evident at present. The current plant landscape clearly reflects the heterogeneity of flora imbued with ecological conditions which are often extremely difficult. Preforest and shrubland groups, which are most often attached to the Pistacio-Rhamnetalia and Rosmarinetea, undoubtedly dominate. It is obvious that the sylvatic atmosphere still persists in the high altitude areas which should be attached to the Quercetea ilicis of which it has some of the characteristics. This situation is the consequence of the Mediterranean influence (North side) linked to hydric compensation in relation to an atmospheric humidityhigh rate, but also and above all, linked to orographic contributions. In the current bioclimatic context, the plant structures are distributed between two stages, which vary from the thermo- to the meso-Mediterranean.

The extent of the dry period imposes on the vegetation a strong evapotranspiration and on the landscape a vegetal cover rich in xerophyte species (Calyeotome, Asparagus, Ulex) favoring the fire. On this subject, and with regard to the northern limits, synthesis works have been carried out over the last decades; Aime (1991) on the Oran coast, Bouazza (1991, 1995) and Bekkouche (2013) in the Tlemcen region; have shown the importance of changes in certain climatic parameters, and especially the rainfall, which generally led Barbero and Quézel (1995) to a drop in bioclimatic level (Emberger, 1955).

The progressive increase of the population and its livestock created a need and which could, duringsometime, cause an increase in the plant cover destruction leading imperatively to the 
constitution of ephemeral swards where dominate the toxic and/or not appetivethorny species such as: Centaurea, Calycotome spinosa, Urginea maritima, Ulex boivinii, Asphodelus microcarpus, Echium vulgare and Atractylis humilis.

The existence of annual species, most often in the form of a doormat, characterizes strongly anthropized shrublands (scrubland/scrub, Cherifi, 2013).

In addition to these shrublands, the Tuberrarieta guttatae and Stellarietea mediae species dominate the landscape. This is clearly understood when we see that the transhumance is done in an early manner from the South to the North and according to the places accessible to the herds (seasonal variations: HAPE for 1913-1938 and then HPAE for 1975-2016). This tendency to seasonal shift in most of the study area has been well sensed by nomadic pastoralists, who are coming earlier in the summer pastures.

In addition, on the southern slope, in contact with these shrublands, swards bring to gether the perennial xeric herbaceous associations which dominate, with rigorous vitality, and it is not on the vegetation of the northern slope that we can observe them. On the other hand, this interpretation is further justified by the fact that on the latter hygrophilic species exist but do not dominate, such as for example Lonicera implexa, Teucrium, Muscari neglectum and Orchis sp. (Moutas Reserve) and it is at this level that the species that characterize the Quercetum ilicis association crumble to give way to those linked to Pistacio-Rhamnetalia and Rosrnarinetea. What is sure is that the thermal requirements clearly explain the increasing continuity of the lentisk stands linked to the Pistacio-Rhamnetalia.

No doubt these stands should be reconsidered as a form of barrier to pure sylvigenesis linked to the Quercetea ilicis. It was a profound change in socio-economic conditions that brought man to this anarchic exploitation, hence the vegetation fire issue is posed in an increasing way.

\section{References}

Aime, S. 1991. Etude écologique de la transition entre les bioclimats sub-humide, semi-aride et aride dans l'étage thermo-méditerranéen du Tell oranais (Algérie nord occidentale). Thèse d'Etat. Univ. Aix Marseille III, 190 pp.

Amara, M. and Bouazza, M. 2013. Contribution à l'étude des groupements à Pistacia atlantica Desf. subsp. atlantica dans la Plaine de Maghnia (Extrême nord-Ouest Algerien). European Journal of Scientific research. 99(1): 22-35.

Babali, B. 2014. Contribution à une étude phytoécologique des monts de Moutas (Tlemcen- Algérie occidentale): Aspects syntaxonomique, biogéographique et dynamique. Thèse de doctorat en Ecologie. Univ. Aboubakr Belkaïd - Tlemcen, 198 pp.

Babali, B., Bouazza, M. and Hasnaoui-Benammar, H. 2018. Sur la découverte des taxa de l'Ophyrys atlantica dans la région de Tlemcen-Algérie. J. Eur. Orch. 50(1): 88-100.

Babali, B., Hasnaoui, A. and Bouazza, M. 2013. Note on the vegetation of the Mounts of Tlemcen (Western Algeria): Floristic and phytoecological aspects. Open Journal of Ecology. 3(5): 370-381.

Barbero, M., Quezel, P. and Rivas-Martinez, S. 1981. Contribution à l'étude des groupements forestiers et pré- forestiers du Maroc. Rev. Phytocoenologia. 9(3): 311-412.

Barbero, M. and Quézel, P. 1995: Desertification, desertisation, aridification in the Mediterranean region and "global change". In: Bellan, D., Bonin, G. \& Emig, C. (Eds), Functioning and dynamics of natural and perturbed ecosystems., pp. 549-569.

Bekkouche, A. 2013. Evolution du paysage steppique dans le sud de Tlemcen (Algérie occidentale). Thèse de doctorat en Ecologie. Univ. Aboubakr Belkaïd - Tlemcen, 129 pp.

Belhacini, F. 2015. Contribution une étude floristique et biogéographique des matorrals du versant sud de Tlemcen (Algérie occidentale). Thèse de doctorat en Ecologie. Univ. Aboubakr Belkaïd-Tlemcen, $154 \mathrm{pp}$. 
Benabid, A. 1985. Les écosystèmes forestiers et pré forestiers du Maroc : diversité, répartition biogéographique et problèmes posés par leur aménagement. For. méd., 7(1):53-67.

Bouazza, M. 1991. Etude phytoécologique de la steppe à Stipa tenassicima L. et à Lygeum spartum L. au sud de Sebdou (Oranie - Algérie). Thèse de doctorat. Univ Aix-Marseille, 119 pp.

Bouazza, M. 1995. Etude phytoécologique de la steppe à Stipa tenassicima L. et à Lygeum spartum L. au sud de Sebdou (Oranie-Algérie). Thèse de doctorat. Es-sciences Biologie des organismes et populations. Univ. Tlemcen, 153pp.

Bouazza, M. and Benabadji, N. 1998. Composition floristique et pression anthropozoïque au Sud - Ouest de Tlemcen. Rev. Sci. Tech. Univ. Constantine n 10. Algérie, pp. 93-97.

Bouazza, M. and Benabadji, N. 2000. Contribution à une étude bioclimatique de la steppe à Artemisia herbaalba Asso. Dans l'Oranie (Algérie occidentale). Rev. Sécheresse. 11(2): 117-123.

Bouazza, M. and Benabadji, N. 2002. Contribution à l'étude du cortège floristique de la steppe au sud d'El Aricha (Oranie- Algérie). Rev. Sci. Thechn. D: 11-19.

Bouazza, M. and Benabadji, N. 2010. Changements climatiques et menaces sur la végétation en Algérie occidentale. Changements climatiques et biodiversité. Vuibert-APAS, Paris, pp.101-110.

Bouazza, M., Benabadji, N. and Hasnaoui, O. 2015. Note sur la typologie des steppes de la région de Tlemcen. Biocénose. 1(1): 49-58.

Bouazza, M., Loisel, R. and Benabadji, N. 2001. Bilan de la flore de la région de Tlemcen (Oranie - Algérie), Rev. Fort. Medit. 22(2): 130-136.

Braun-Blanquet, J. 1936. Un joyau floristique et phytosociologique : l'Isoetion méditerranéen. Comm. SIGMA, Bull. Soc. Sci. Nat. Nîmes, 47: 1930-193547.

Braun-Blanquet J., Molinier R., and Wagner H., 1940. Cisto-Lavanduletea (landes siliceuses à cistes et lavandes). Prodr. Group. Vég., Montpellier, 7: 55.

Braun-Blanquet J. 1952. Phytosociologie appliquée Comm. S.I.G.M.A, n¹16.

Braun-Blanquet, J. and De Bolos, 0. 1957. Les groupements végétaux du bassin moyen de l'Ebre et leur dynamisme. Ama!' Estac. Exper. Aula Dei, S(1-4): 266, + tableaux.

Braun-Blanquet, J. 1925. Une connaissance phyto-sociologique dans le brianconnais. Bul. Soc. Bot. 73 pp.

Braun-Blanquet, J. 1931. Aperçu des groupements végétaux du bas Languedoc. Communication S.LG.M.A. n09. Marseille.

Braun-Blanquet, J. 1947. Le tapis végétal de la région de Montpellier et ses rapports avec le sol. Comm. SIGMA, 94: 1-306.

Braun-Blanquet, J. 1954. La végétation alpine et nivale des Alpes françaises. Comm. SIGMA. 125 pp.

Braun-Blanquet, J. 1965. Plant sociology, Translated by Fuller and Conrad, New- York and London, 469 pp.

Chaabane, A. 1993. Etude de la végétation du littoral septentrional de Tunisie : Typologie, syntaxonomie et éléments déménagèrent. Thèse Doct. Es-Sci. en Ecologie. Univ. Aix-Marseille III, 123 pp.

Cherifi, K. 2013. Impact de l'action anthropozoogéne sur la biodiversité végétale de l'écosystéme forestier du Djebel Tassala (Algérie occidentale). Thèse Doct. Univ. Sidi Bel Abbes, 129 pp.

Cherifi, K., Mehdadi, Z., Elkhiati, N., Latreche, A. and Ramdani, M. 2017. Floristic composition of the mountainous massif of Tessala (Algerian West): Biodiversity and regressive dynamics of the forest ecosystem. J. Mater.Environ. Sci. 8(9): 3184-3191.

Cherifi, K., Mehdadi, Z., Latreuch, A. and Bachir Bouidjra S.E. 2011. Impact de l'action anthropozoogène sur l'écosystème forestier du mont de Tessala (Algérie occidentale). Rev. Sécheresse. 22(3): 197-206.

Chiali, L. 1999. Contribution à une étude syntaxonomique des matorrals de la région de Tlemcen. Thèse d'ingénieur d'état en Ecologie. Univ. Tlemcen, 130 pp.

Dahmani, M. 1984. Contribution à l'étude des groupements à chêne vert (Quercus rotundifolia L. arnk) des Monts de Tlemcen : Approche phytoécologique et phytosociologie. Thèse de Doctorat de $3^{\text {eme }}$ Cycle. USTHB. Alger, $226 \mathrm{pp}$.

Dahmani, M. 1996. Diversité biologique et phytogéographique des chênaies vertes d'Algérie. Rev. Ecologia Mediterranea. 22(4): 19-38.

Dahmani, M. 1997. Le chêne vert en Algérie. Syntaxonomie, phyto-ecologie et dynamique des peuplements. Thèse. Doct. USTHB. Alger, 330 pp. 
Djebaili, S. 1984. Steppe algérienne, phytosociologie et écologie. OPU. Alger, 27 pp.

Djebaili, S. 1990. Syntaxonomie des groupements pre-forestiers steppiques de l'algérie. Rev. Ecologia Mediterranea. 16: 231-244.

El Hamrouni, A. 1978. Etude phyto-ecologique et problèmes d'utilisation de I' aménagement dans les forets de Pin d'Alep de la région de Kassarine (Tunisie centrale). Thèse. Doct. $3^{\text {ème }}$ cycle. Univ. Aix-Marseille III, $193 \mathrm{pp}$.

El Hamrouni, A. 1992. Végétation forestière et pre-forestiere de la Tunisie. Typologie et éléments pour la gestion. Thèse d'Etat. Univ. Aix-Marseille III, pp.19-220.

Emberger, L. 1955. Une classification bio-geographique des climats. Rev. Trav. Labo. Geol. Zool. Fac. Sci. Montpellier, 7: 3-43.

Gharzouli, R. 1989. Contribution à l'étude de la végétation de la chaine des Babors et Tababort. Thèse de Magistère. INES de Biologie. Sétif, 235 pp.

Goodall, D.W. 1952. Quantitative aspects of plant distribution. Biological Reviews, 27: 194-245.

Gounot M., 1969 - Méthodes d'étude quantitative de la végétation. Masson, Paris.

Guinochet M., 1973. Phytosociologie. Masson Edit. Paris, 227 pp.

Guinochet, M. 1977. Contribution à la systématique des pelouses therophytiques du nord de la Tunise et de

l'Algérie. Colloques phyto-sociologiques VI. Les pelouses sèches. Lille, 21 pp.

Hadjadj-Aoul, S. 1995. Les peuplements à Thuya de Berberie en Algérie. Phytoécologie, syntaxonomie, potentialités sylvicoles. Thèse. Doct. es-Sci, Univ. Aix-Marseille III, 159 pp.

Hadjadj-Aoul, S. 1988. Analyse phyto-ecologique du Thuya de Barbarie (Tetraclinis articulata Vahl, Master) en Oranie. Thèse de Magistere. Univ. d'Oran, pp. 131-150 + annexes.

Hadjadj-Aoul, S. 1991. Les peuplements de Tetraclinis articulata sur le littoral d'Oran (Algérie). Ecologia mediterranea XVII, pp. 63-78.

Hasnaoui, O. 2008. Contribution à l'étude des Chamaeropaies dans la région de Tlemcen, Aspects botanique et cartographiques. Thèse. doct. Univ. Aboubakr Belkaïd- Tlemcen, 210 pp.

Le Houerou, H.N. 1969. La végétation de la Tunisie steppique avec référence aux végétations analogues d'Algérie, de Libye et du Maroc. Ann. Inst. Nat. Agro. Tunis, 561 pp.

Loisel, R. 1971. Séries de végétation propres en Provence aux massifs des Maures et de l'Esterel. (Ripisylves exclues). Bull. Soc. Bot. France, 1181: 203-236.

Médai 1, F. and Quézel, P. 1996. Sign ification cl imatiq ue et phytoécologique de la redécouverte en France méditerranéenne de Chamaerops humilis L. (Palmae). - C. R. Acad. Sci. Paris, Sc iences de la vie/Life Sciences, 319: 139-145.

Mesli. K., Bouazza, M., Godron, M. and Vela, E. 2009. Diagnostic écologique de reboisements dans le parc national de Tlemcen. Rev. Acta botanica gallica, 156(2): 283-294.

Quézel P. and Rivas-Martinez S., 1980. A propos de la valeur bioclimatique et dynamique de quelques essences forestières au Maroc. Ecol. Medit. 5:211-249.

Quézel, P., Barbero, M., Benabid, A. and Rivas-Martinez, S. 1992. Contribution à l'étude des groupements forestiers et pre-forestiers du Maroc oriental. Rev. Studia Botanica, 10: 57-90.

Quezel P., 2000. Réflexion sur l'évolution de la flore et de la végétation au Maghreb Méditerranéen. Ibis. Press. Edit. Paris, 117 pp.

Quézel, P. and Barbero, M. 1981. Contribution à l'étude des formations pre-steppiques à genévriers au Maroc. Bol. Soc. Brot. Sen. 53(2): 1137-1160.

Quézel, P. and Barbero, M. 1986. Aperçu syntaxonomique sur la connaissance actuelle de la classe des Quercetea ilicis au Maroc. Rev. Ecologia Mediterranea, 12(4): 105-111.

Quézel, P. and Medail, F. 2003. Ecologie et biogéographie des forêts du bassin méditerranéen. Lavoisier, Paris, 592 pp.

Quézel, P., Barbero, M., Benabid, A. and Rivas-Martinez, S. 1992. Contribution à l'étude des groupements forestiers et pre-forestiers du Maroc oriental. Rev. Studia Botanica, 10: 57-90. 
Quézel, P., Barbero, M., Benabid, A. and Rivas-Martinez, S. 1994. Le passage de la végétation méditerranéenne à la végétation saharienne sur le revers méridional du Haut Atlas oriental (Maroc). Phytocoenologia, 22(4): 537-582.

Rivas-Goday S. 1964. Vegetacion y £lorula de la Cuenca extrema del guadiana. Publ. Exma. Diput. de Badajoz, Madrid, pp. 1-777.

Rivas-Goday S. 1957. Contribucion el estudio de la clase Quercetea ilicis hispanica. Ann. Inst. Bot. A.J; Cavanilles, 17 (2): 285-406.

Rivas-Martinez S., Bascones J.C, Diazt E., Fernandez-Gonzalee F.et Loindij., 1991. Vegetation del PIRINEO OCCIDENTAL y Navarra. Itenera Geobo-t., 5:5-456.

Rivas-Martinez, S. 1974. La vegetación de la clase Quercetea ilicis en Espana y Portugal. Ann. Inst. Bot. A.J; Cavanilles, 31(2): 205-259.

Rivas-Martinez, S. 1977. Datos sobre la vegetacion nitrophila española. Rev. Acta Bot. Malacitana, 3: 159167.

Rivas-Martinez, S. and Izco, J. 1977. Sobre la Vegetación Terofitica Subnitrofila Mediterranea (Brometalia rubenti - tectori). Anal. Inst. Bot. Cavanilles, 34(1): 355-581.

Rivas-Martinez, S., Costa, M., and Itzco, J. 1984. Sintaxonomia de la clase Quercetea ilicis in el Mediterraneo occidental. Not. Fitosoc. 19(2) : 71-98.

Rivas Martinez, S., 1987. Memoria y mapa de las series de vegetación de España. 1:400.000.ICONA. Serie Técnica. MAPA. Madrid

Seltzer P. 1946. Le climat de l'Algérie. Inst. Météor. et de Phys. du Globe. Alger. 219 pp.

Stambouli-Meziane, H. 2010. Contribution à l'étude des groupements à psammophiles de la région de Tlemcen (Algérie occidentale). Thèse. Doct. Univ. Abou Bakr Belkaid-Tlemcen, 226 pp. 